\title{
COVID-19 Aşısı ve Yalan Haber: Aşılanma Öncesinde Bireylerin Yalan Haber İçeriklerini Fark Etme, Takip Etme ve Teyit Etme Eğilimlerinin Belirlenmesi
}

\author{
Yıldıray Kesgin \\ Dr. Öğr. Üyes \\ Üsküdar Üniversitesi Illetişim Fakültesi \\ yildiray.kesgin@uskudar.edu.tr \\ ORCID: 0000-0001-6535-9151 \\ Derya Gül Ünlü \\ Doç. Dr. \\ İstanbul Üniversitesi İletişim Fakültesi \\ derya.gul@istanbul.edu.tr \\ ORCID: 0000-0003-3936-7988
}

\begin{abstract}
The COVID-19 Vaccine and Fake News: Determining Individuals' Tendency to Recognize, Follow and Confirm Fake News Content Before the Vaccination

With the completion of the production of COVID-19 vaccines and the start of the vaccination process, news content that does not reflect or distorts the truth about the nature and possible side effects of vaccines as well as news content that conveys accurate information has been circulated in both traditional and digital media. In this study that realized before the start of the vaccination process in Turkey, it was aimed to determine the awareness levels of individuals about the news content about the vaccine and to reveal their tendencies to follow, to confirm, to trust and to attach importance to the news in question. As a result of the study, it has been determined that individuals do not find the vaccine news in the media reliable and informative enough; that they think that there is too much fake news content in the social media; that while attaching
\end{abstract}


importance to the statements of the Minister of Health about the vaccine, they also follow the news about the vaccine by comparing from different sources; and that they state that the discussions about the vaccine published in the media do not affect their attitudes toward COVID-19 vaccine.

keywords: COVID-19, COVID-19 vaccine, COVID-19 vaccine news, disinformation, fake news

\section{Résumé}

\section{Le vaccin COVID-19 et les fausses nouvelles : déterminer la tendance des individus à reconnaître, suivre et confirmer le contenu des fausses nouvelles avant la vaccination}

Avec l'achèvement de la production de vaccins COVID-19 et le début du processus de vaccination, un contenu d'actualités qui ne reflète pas ou qui déforme la vérité sur la nature et les éventuels effets secondaires des vaccins ainsi que des contenus d'actualités qui transmettent des informations précises ont été diffusés dans les médias traditionnels et numériques. Dans cette étude réalisée avant le début du processus de vaccination en Turquie, il s'agissait de déterminer les niveaux de sensibilisation des individus sur le contenu de l'actualité sur le vaccin et de révéler leurs tendances à suivre, à confirmer, à faire confiance et à attacher de l'importance à l'actualité en question. À la suite de l'étude, il a été déterminé que les individus ne trouvent pas les informations sur les vaccins dans les médias suffisamment fiables et informatives; qu'ils pensent qu'il y a trop de fausses informations dans les médias sociaux ; que tout en attachant de l'importance aux déclarations du Ministre de la Santé au sujet du vaccin, ils suivent également l'actualité du vaccin en comparant de différentes sources; et qu'ils déclarent que les discussions sur le vaccin publiées dans les médias n'affectent pas leurs attitudes envers le vaccin COVID-19.

mots-clés: le COVID-19, le vaccin COVID-19, les nouvelles sur le vaccin COVID-19, la désinformation, les fausses nouvelles. 


\section{Öz}

COVID-19 aşılarının üretiminin tamamlanması ve așılama sürecinin başlamasıyla birlikte, medyada doğru bilgi aktaran haber içerikleri kadar aşıların niteliği ve olası yan etkilerine ilişkin çok fazla gerçeği yansıtmayan ya da çarpıtan haber içeriği de hem geleneksel hem de dijital medyada dolaşıma girmiştir. Türkiye'de COVID-19 aşısının uygulanmaya başlanması süreci öncesinde gerçekleştirilen çalışmada, bireylerin aşı hakkındaki haber içeriklerine dair farkındalık düzeylerinin belirlenmesi ve söz konusu haberleri takip etme, teyit etme; ilgili haberlere güvenme, önem verme eğilimlerinin ortaya koyulması amaçlanmıştır. Bu amaç doğrultusunda, soru formu aracılığıla betimsel yönteme dayalı bir alan araştırması gerçekleştirilmiştir. Çalışma sonucunda ise, bireylerin medyadaki aşı haberlerini güvenilir ve yeterince bilgi verici bulmadıkları, sosyal medyada çok fazla yalan haber içeriği olduğunu düşündükleri, Sağlık Bakanı'nın aşıyla ilgili açıklamalarına önem vermekle birlikte aşıyla ilgili haberleri farkı kaynaklardan da karşılaştırarak takip ettikleri ve medyadaki aşı tartışmalarının COVID-19 aşısına ilişkin tutumlarını etkilemediğini belirttikleri ortaya koyulmuştur.

anahtar kelimeler: COVID-19, COVID-19 aşıSI, COVID-19 aşı haberleri, dezenformasyon, yalan haber. 


\section{Giriş}

Tüm dünyayı etkisi altına alarak, her geçen gün artan sayıda ölüme neden olan COVID-19 virüsü kaynaklı salgına karşı ciddi önlemler alınmış ve kısa sürede birçok farklı ülkede aşı çalışmaları başlatılmıştır. Söz konusu aşıların testlerinin tamamlanması ve uygulanabilir hale gelmesiyle birlikte, yapılan aşı haberleri ve haber içerikleri üzerinden sürdürülen aşı tartışmaları da artmıştır. Bilgi arayan bireyler tarafından aşı haberlerinin yakından takip edildiği bu süreçte, medyada, COVID-19 aşılarına ilişkin çok fazla görüşe yer verilmiş, geleneksel ve dijital çok sayıda platform üzerinden COVID-19 aşısı uygulamasının olası sonuçları tartışmaya açılmıştır. Bu çerçevede doğru bilgi aktaran haberler kadar, aşıların niteliği ve olası yan etkilerine dair gerçeği yansıtmayan ya da çarpıtan haber içerikleri de hem geleneksel hem de dijital medyada yer almıştır. Özellikle dijital medyada içeriklerin herhangi bir filtreden geçmeksizin paylaşllabilmesi ve dijital ortamdaki bilgilerin kolaylıkla değiştirilebilir, çalınabilir, çarpıtılabilir veya sahte ifadelerle anonim olarak oluşturulabilmesi (Metzger, 2007, s.2079), aşı hakkında çok fazla gerçek dışı içeriğin de kullanıcılar arasında hızla yayılmasını beraberinde getirmiştir. Öyle ki konuyla ilgili üretilen bilgi bolluğunda gerçek bilgileri yanlıştan ayırmanın zorluğu nedeniyle bu durum Dünya Sağlık Örgütü (2020) tarafından infodemi olarak adlandırılmıştır.

COVID-19 virüsü hakkında çoğu zaman okuyucuların güvendiği kaynaklardan da gelebilen yalan haberler (Ljungholm ve Olah, 2020; Ülker, 2021) ve yine medyada bu yalan haber içeriklerine dayanılarak sürdürülen tartışmalar, bireyler arasında hızlıca yayılmaktadır. Gerçek dışı ya da gerçeği çarpıtan bu haberlere olan inanç ise, hastalığa dair alınabilecek önlemler hakkında bireyleri yanlış yönlendirebilmekte (Sceri ve Grech, 2020), kısıtlamalara uyularak gerekli önlemlerin alınmasını engelleyebilmektedir (Ülker, 2021). Virüsün yayılımının yavaşlatılmasına ilişkin bahsi geçen önlemlerin başında ise, COVID-19 aşısı uygulanmalarının geldiğini söylemek mümkündür. Konuyla ilgili yalan haber ve COVID-19 aşı kabulü arasındaki ilişkiye odaklanan araştırmaların sonuçları, bireylerin yalan haber içerikleri nedeniyle aşının niteliğine kuşkuyla yaklaşmaları ve aşının önemli yan etkilerinin olacağını düşünmelerinin (Catalan-Matamoros ve Elias, 2020; Loomba vd., 2021; Marco-Franco vd., 2021; Roozenbeek vd., 2020; Sallam vd., 2021) aşı kabulünü olumsuz etkilediğini; yalan haber içeriklerini fark ettiklerinde ise aşı olma kararlarının olumsuz yönde etkilenmediğini (Montagni vd., 2021) ortaya koymaktadır. Dolayısıyla aşının olası yan etkilerine dair fark edilemeyen yalan haber içeriklerinin bireylerin COVID-19 aşısını olma kararlarının önünde bir engel teşkil edebileceğini söylemek yanlış olmayacaktır. Bu bakımdan ele alındığında, Türkiye'de aşılama sürecinde bireylerin haber içerikleri hakkındaki düşüncelerinin ve yine söz konusu haberleri takip etme, güvenme, teyit etme, önem verme eğilimlerinin belirlenebilmesinin, bireylerin aşıyla ilgili haber içeriklerine ilişkin tutumlarının ortaya koyulabilmesi açısından önem taşıyacağı düşünülmektedir. Buna ek olarak, COVID-19 aşılarının uygulanma sürecinde medyadaki yalan haber içeriklerinin aşı tereddüdü üzerindeki önemine vurgu yapan ve haber içerikleriyle ilişkili olarak bireylerin tu- 
tumlarını ölçümleyen farklı ülkelerden çok sayıda çalışmayla (İngiltere ve Amerika (Loomba vd., 2021), Kanada (MacDonald, 2020), İtalya (Carrieri vd., 2019; Moscadelli vd., 2020), İspanya (Catalan-Matamoros ve Elias, 2020; Eguia, 2021), Ürdün (Sallam vd., 2021), Mısır (Saied vd., 2021), Romanya (Palade ve Balaban, 2020), Hindistan (Jain vd., 2021), Brezilya (Ceron vd., 2021) gibi) karşılaşılmakla birlikte, Türkiye'de benzer bir betimsel çalışmaya rastlanılmamıştır. Bu bakımdan gerçekleştirilen araştırmanın bir Türkiye perspektifi de sunması dolayısıyla alan yazınındaki boşluğu dolduracağını da söylemek olanaklıdır. Bu kapsamda aşağıda öncelikle dezenformasyon ve yalan haber kavramları ele alınarak, pandemi sürecinde yalan haberin yayılımı ve COVID-19 aşısıyla ilgili yalan haber içeriklerine yer verilecek; sonrasında ise, araştırma bulguları aktarılacaktır.

\section{Dezenformasyon ve Yalan Haberin Yayılımı}

Yanlış bilgiyi üretmek, yaymak ya da var olan bilgileri niyetli biçimde çarpıtarak vermek, kitleleri etkileyebilecek potansiyele sahip ve geçmişi çok eskilere dayanan yöntemlerdir. Kitle iletişiminin yaygınlaşmasıyla birlikte, neredeyse, tüm rejimlerde karşı propaganda olarak dezenformasyondan yararlanılmıştır. İktidar arayışından doğan geniş kitleleri etkileme intiyacı içerisinde yalan haber, bir propaganda aracı olarak, dezenformasyon içeren bilginin yayılmasında kullanıımıştır. Antik çağdan günümüze dek kamuoyunu etkilemek için yararlanılan yalan haberin tarihi oldukça eskilere dayanmakla birlikte (Lazer vd., 2017), gerçek dışı haberin yayılma alanının ve hızının artması, medya teknolojilerinin gelişimine paralellik göstermektedir. Çeşitli tarafların çıkarlarına uygun olarak yapılan yalan haber, her dönem iktidarlar tarafından üretilmekte ve iletişim kanalları aracılığıyla yayılmaktadır.

Özellikle totaliter rejimlerde karşı ya da hasım rejim için kullanılan sahte belgeler, montaj görüntüler, çeşitli dedikodular ve karalamalar medyada yer bulmuştur. Daha demokratik rejimlerde ise bu eylemler hem karşı ya da hasım rejim için hem de iktidara rakip gruplar ve muhalif sesler için kullanılan bir taktik olmuştur. Örneğin; Stalin hükümetinin dezenformasyon içeren en büyük iddiası Hitlerin ölmediği hakkındadır. Stalin, Temmuz 1945'teki Potsdam Konferansı'nda Hitler'in nasıl öldüğü sorulduğunda, ya "İspanya'da ya da Arjantin'de" yaşadığını iddia etmiştir (Beschloss, 2002). Stalin hükümeti tarafından propagandası yapılan bu dezenformasyon, Batılı güçlerin resmi sonucuna ve tarihçilerin 30 Nisan 1945 'te Hitler'in kendisini öldürdüğü yönündeki fikir birliğine rağmen, karşıı̆̆ını bulmuş, dünyanın en çok tartışılan komplo teorileri arasında yerini almıştır. (Eberle ve Ulh, 2005, s.288; Kershaw, 2000, s.1038). Diğer yandan dezenformasyonun sadece karşı propaganda için yapılmadığını da belirtmek gerekmektedir. Örneğin; Çok miktarda kanıta, toz ve kaya örneklerine, televizyon görüntülerine ve buna tanıklık eden yüz binlerce insana rağmen, anketler, Amerikalıların \%6'sının Apollo 11 astronotlarının aya hiç inmediğine inandığını göstermektedir (Schwartz, 2019). Ay'a gidilmediği hakkındaki bu dezenformasyon, Ay'a ayak basılmasından sadece bir yı sonra, Vietnam Savaşı'na bir tepki olarak toplum tarafından yayılmış, savaş istemeyen Amerikalılar aya ayak basmanın gerçek olmadığına dair bir 
inanç oluşturmuştur. Konuyla ilgili olarak, 1970 yılında yapılan bir anket, AmerikaIıların \%30'unun Apollo 11'in sahte olduğunu düşündüklerini ortaya koymuştur (Schwartz, 2019). Ayrıca, o dönemin teknolojik yeterliliğiyle çekilen filmlerin insanlara oldukça gerçekçi gelmesi de aya ayak basma görüntülerinin gerçek olmayacağı inancını güçlendirmiştir. Bu çerçevede değerlendirildiğinde, gerçek dışı ya da gerçeğin çarpıtılmış bir versiyonunu sunan enformasyonun niyetli bir biçimde çeşitli ideolojilere ve siyasal sistemlere hizmet ya da tepki amacıyla kullanıldığını söylemek mümkündür.

Geleneksel medya kuruluşları, çeşitli şirketler ya da troller aracılığıyla çok farklı amaçlarla yalan haber ve yanlış enformasyonunun yayıldığı bilinmektedir (Ünal ve Taylan, 2017, s.82). Günümüzde ise, özellikle dijital iletişim ortamlarının yaygınlaşmasıyla birlikte, doğru olmayan enformasyonun hızlı yayılımı, bilgi kirliliği ve yalan/sahte haber gibi kavramlarla yeniden okunur olmuştur. Bu bağlamda, Wardle ve Derakhshan (2017, s.5) bilgi kirliliğini tanımlamak için yeni bir kavramsal çerçeve sunmaktadır. Bu kavramsal çerçeve mezenformasyon (misinformation), dezenformasyon (disinformation) ve malenformasyon (malinformation) olmak üzere üç farklı bilgi kirliliği türünün tanımlanması ve söz konusu türler arasındaki zarar ve sahtelik boyutlarının belirlenmesini içermektedir. Buna göre, araştırmacılar adı geçen üç farklı bilgi kirliliği türünü şöyle açıklamaktadır:

- Mezenformasyon: yanlış bilginin kasıtsız olarak paylaşılması.

- Dezenformasyon: yanlış bilgilerin zarar vermek için kasıtlı olarak paylaşılması.

- Malenformasyon: bir kişiye, organizasyona veya ülkeye zarar vermek için kullanılan gerçekliğe dayanan bilgilerin paylaşıması.

Bir kategorizasyon sunan bu tanımlama, günümüzde iyice kompleks hale gelen yanlış bilginin ve yanlış bilgiye dayanan yalan/sahte haberin nasıl konumlandığının anlaşılabilmesi açısından da önem taşımaktadır. Yalan haber kavramı, en genel anlamıyla, "gazetecilik prensipleri altında toplanan enformasyonun doğrudan yanlış veya yanıltıcı içerik olarak maskelenmesi" olarak tanımlanmaktadır (Reuters, 2017). Yalan haberin bilgi kirliliğinin oluşması sürecinde endişe verici nitelik taşımasının nedenleri ise şu maddelerle açıklanmaktadır (Newman vd., 2017, s.19): (1) para kazanmak ya da başkalarının itibarını sarsmak için 'uydurulması'; (2) aslında gerçeğe dayanması ama belirli bir gündeme uygun olarak 'tasarlanması'; ve (3) insanların kendilerini rahat hissetmediği ya da aynı fikirde olmadığı haber içeriklerini kapsaması.

Sosyal medyanın ortaya çıkışıyla birlikte, dijital içerik bir denetim mekanizmasına dahil olmadan üretebilir ve ağlar aracılığıyla hızla yayılabilir hale gelmiştir. Bu bağlamda ele alındığında, kullanıcıların çevrimiçi ekosistemde gerçeği yansıtmayan zararlı içeriğin çeşitli biçimleriyle çoğu zaman da bilinçsizce karşılaşmalarının, sosyal medyada yayılan yanlış bilgiden kaynaklı tehlikenin başında geldiğini söylemek mümkündür (Schapals, 2018). Ayrıca sosyal medya siteleri kullanıcılarına algoritma- 
lar aracılığıyla düzenlenmiş bir haber akışı sunmaktadır. Söz konusu algoritmalar, kullanıcının karşılaşacağı içerikleri düzenlerken onun önceki tercihlerini dikkate almakta ve buna uymayan içerikleri de eleme eğilimindedir. Bu durum ise, bireylerin sosyal medyada karşılaştıkları içerikler üzerinden bir filtre balonuna hapsolmasına neden olarak alternatif içeriklerle karşılaşmasını zorlaştırmakta ve kendi dünya görüşünü pekiştirmesini beraberinde getirmektedir (Gül-Ünlü ve Kesgin, 2021; Pariser, 2011). Konuyla ilgili olarak Schwartz ve Jalbert (2020), filtre balonlarının kullanıcıların kendi görüşlerinin doğru ve diğerlerinin görüşlerinin en iyi intimalle yanlış ve en kötü intimalle kötü niyetli olduğundan emin olmalarını sağladığının altını çizmektedir. Bu bakımdan değerlendirildiğinde, özellikle sağlıkla ilgili yanlış bilgi veren içeriklerle filtre balonları aracılığıyla sıklıkla karşılaşımasının o bilgiye olan inancını güçlendirerek, bilimsel açıklamaların göz ardı edilmesine neden olabileceğini söylemek mümkündür. Hatta karşılaşılan bu yanlış sağlık bilgilerinin çoğunlukla uzman olduğu düşünülen taraflarca destekleniyor oluşu ve alternatif görüşlerin bulunmaması da söz konusu bilginin gerçekliğine olan inanışı güçlendirmektedir.

İnsanların sağlıklarını bozabilecek hatta hayatlarını kaybetmelerine yol açabilecek yanlış bilgi yayılımının pandemi süreci öncesinde de gündeme geldiği görülmektedir. Örneğin; 2018 yılının başlarında, Tide deterjan kapsüllerinin piyasaya sürülmesiyle, gençlerin bu kapsüllerin yemelerini ve görüntülerini kaydederek, başkalarına da bu kapsülleri yemeleri için meydan okudukları bir akım ortaya çıkmıştır. Kökeninin 2013 yılında bir soru cevap sitesi olan The Straight Dope'da sorulan bir soru ya da 2015 yllında The Onion isimli bir hiciv içerikli internet gazetesinde yayınlanan bir makale olduğu belirtilen bu akım, kısa sürede bir internet "meme"ine dönüşmüştür. Bu süreçte üretici olan kurum yetkilisi ve hükümet yetkilileri, deterjan yemenin zararlarına ilişkin çeşitli açıklamalar yapmış, tepkiler nedeniyle Youtube ve Facebook ilgili görüntüleri kaldırmış, fakat bu akım çok sayıdaki gencin zehirlenmesi ve 10 gencin ölümüyle son bulmuştur (Mc Dowra, 2018). Bu bağlamda ele alındığında, dijital ortam üzerinden yayılan enformasyonun denetlenememesi nedeniyle ahlaki bir filtreye de takılmadığı ve insan sağlığını tehlikeye atacak sonuçları beraberinde getirdiğini belirtmek olanaklıdır. Dolayısıyla sosyal ağlar aracılığıyla yayılan yalan ya da gerçek dışı bilginin (yani bu örnekte görüldüğü üzere deterjan yemenin zararlı olmadığı bilgisinin), söz konusu bilgiyle karşılaşan kullanıcılar için gerçek sonuçları olduğu ortadadır.

Bununla birlikte, içinde bulunduğumuz post-truth döneminde yalan haber içerin yayılımının da ivme kazandığını eklemek gerekmektedir. Artık doğru haber vermenin öneminin eskisi kadar kıymetli olmadığı bir çağda, yalanların ve doğruluğu kanıtlanmamış enformasyonun arkasında duran insanların da kendilerini ifade edebildikleri medyalar geniş kitlelere ulaşabilir hale gelmiştir. Bilginin güç olduğu ve bilgiyi elinde bulunduranların hakimiyet sağladığı bu dönemde, gerçek ve objektif bilgiye daha fazla intiyaç duyulmaktadır. Çünkü küresel dünya düzeninde artık daha çok tek yönlü seçicilik, dezenformasyon ve manipülasyon tehlikesi yaşanmaktadır (Kiraz, 2019, s.12). Bu kapsamda algoritmaların oluşturduğu yankı odaları ve filtre balonları gibi sosyal medyada tek yönlülüğü destekleyen mekaniz- 
malar da enformasyonun bilgi üretimine dönüşememesine, fikirlerin karşılaştırılarak ya da bilimsel yöntemlerle açıklanarak doğrulanamamasına neden olmakta ve küresel düzeyde yürütülen ayrıştırma politikalarını desteklemektedir. Bu durum ise, yalan haberin yalan olduğunun ortaya çıkmaması ve alternatif görüşlerin dolaşım bulamaması ile sonuçlanmaktadır.

\section{Pandemi Sürecinde Yalan Haber}

Korona virüsün bilinmeyen bir versiyonu olan ve sonrasına COVID-19 olarak adlandırılan yeni bir virüs tarafından enfekte olan ilk hasta Çin Wuhan kentinde 1 Aralık 2019 tarihinde tespit edilmiştir. 16 Aralık günü Wuhan'da virüs taşıyan ilk hastanın hastanede bulunduğu kabul edilmiş, 31 Aralık'ta ise Çin, yeni tip bir korona virüsü belirlediğine dair Dünya Sağlık Örgütü'nü resmen bilgilendirmiştir. Koronavirüs kaynaklı ilk ölüm Wuhan'da 9 Ocak 2020 tarihinde gerçekleşmiş, virüsün yayılımı hızla armış ve 23 Ocak tarihinde tüm şehir karantinaya alınmıştır. 10 Ocak tarihinde ise, virüsün Wuhan şehri dışında görüldüğü açıklanmış, öncelikle diğer Güney Asya ülkelerinde karşılaşılan hastalık hızla tüm dünya ülkelerini sarmış, 31 Aralık tarihinde Dünya Sağlık Örgütü pandeminin dünya çapında yayılmaya başladığını ilan etmiştir. Virüs Avrupa ülkelerinde de hızla görülmeye başlanmış; 24 Ocak'ta Fransa'da, 27 Ocak'ta Almanya'da, 31 Ocak'ta Ingiltere'de ilk vakalara rastlanmıştır (Roberts, 2020, s.617). Türkiye'de ise, ilk vaka 11 Mart 2020 tarihinde tespit edilmiştir (covid19.saglik.gov.tr). Güney Asya'da başlayarak, Avrupa ülkelerine yayılan ve kısa sürede tüm dünyayı etkisi altına alarak, gün geçtikçe artan sayıda ölümlere neden olan ve dünya çapında salgın olarak ilan edilen bu küresel virüse karşı, dünya genelinde tüm devletler ciddi önlemler almış bulunmaktadır.

COVID-19 virüsünün dünya genelinde hızla yayılması, hastalığın ne olduğu, nereden çıktığı, nasıl bulaştığı gibi sorulara ilişkin bilgi intiyacını da beraberinde getirmiş, özellikle sosyal medya kullanıcıları kısa sürede doğruluğu ya da yanlışlığı birbirinden ayrılamayan yoğun bir bilgi akışıyla karşı karşıya kalmışlardır. Ayrıca hastalık hakkında sahteliği kolay anlaşılamayacak görsel, görsel-işitsel içeriklerin yoğun bir biçimde kullanılması ve defalarca paylaşılması (Erkan ve Ayhan, 2018, s.207), kullanıcıların söz konusu haber içeriklerinin gerçekliğini sorgulamalarını ya da teyit etmek için harekete geçmelerini zorlaştırmıştır. Örneğin; pandeminin ilk dönemlerinde hastalığın nereden ve nasıl çıktığı sosyal medyada hakkında en çok içerik üretilen konulardan biri olmuştur. Bu süreçte, Wuhan kentindeki balık pazarı sık sık gündeme gelmiş ve 2016 yılında Güney Pasifik'te çekilmiş olduğu sonradan anlaşılan bir video görüntüsü üzerinden (Mas, 2020), hastalığın bu pazarda satılan yarasaların yenmesiyle ortaya çıktığı hakkında bir kanaat oluşmuştur. Her ne kadar virüsün yarasalar aracılığıyla geçmiş olabileceğini destekleyen bilimsel bir araştırma bulunsa da , çalışmanın yapııdığı alan ve Wuhan kenti arasındaki coğrafi mesafe göz önünde bulundurulduğunda, koronavirüsün bu şekilde yayıldığını söylemek mümkün değildir. Fakat tüm bu dayanaklara rağmen söz konusu videonun etkisiyle, virüsün içilen yarasa çorbası nedeniyle ortaya çıktığı ve yayıldığı bilgisi tüm dünyada Çinlileri ve özellikle de Çinlilerin yemek kültürlerini hedef alan 
bir nefret söylemini beraberinde getirmiştir (Dirini ve Özsu, 2020). Çin hükümeti, videonun 2016 yllına ait olduğu ve Güney Pasifik'te çekildiğine ilişkin hem resmi kanallardan hem kendi sosyal medya hesapları üzerinden açıklamalar yapsa da sosyal medya aracılığıyla yayılan bu inanışın önüne geçilememiştir.

COVID-19 virüsüyle ilgili yalan haberlerin yayııımı, sadece hastalığın kökeni ile de sınırlı kalmamıştır. Örneğin; Mikki Willis tarafından hazırlanan Plandemic, COVID-19 salgını hakkında yanlış bilgi veren ilk komplo teorisi filmine dönüşerek, kısa sürede COVID-19 salgını hakkındaki en yaygın içeriklerden biri haline gelmiştir. Söz konusu videoda COVID-19 virüsünün laboratuvarda üretildiği, grip aşıSı olan kişilerin COVID-19'a yakalanma risklerinin daha yüksek olduğu, maske kullanımının bağışıklık sistemini zayıflatarak, virüsü aktive ettiği, başka hastalıklardan ölenlerin ölüm sebebinin COVID-19 olarak değiştirildiğini ve bunun için doktorlara ödeme yapıldığı gibi birçok iddia ortaya atılmıştır. Sosyal medya kullanıııları arasına uzman görüşü olduğu dile getirilerek, paylaşılan bu videolar pandemi hakkındaki birçok komplo teorisinin yayılmasına da aracılık etmiştir. Dolayısıyla hastalığın nasıl bulaştığı, maske kullanımı, hastalıktan korunma ya da tedavi yöntemleri hakkındaki çok sayıda gerçek dışı içeriğin, geleneksel ve dijital medyada çokça haberleştirilip, paylaşılarak yalan/sahte bilginin yayılmasına neden olduğunu söylemek mümkündür. Bu kapsamda gerçekleştirilen çalışmalar (Boberg vd., 2020; Ceron vd., 2021; Yang vd., 2020), COVID-19 salgını döneminde özellikle yanlış bilgilerin kalıcı olduğunu ve sosyal medyanın bu yanlış bilgi içeren yalan haberlerin öngörülemeyen dolaşımını hızlandırdığının altını çizmektedir. Hatta öyle ki Dünya Sağlık Örgütü Şubat 2020'de mevcut büyük miktarda bilgi ile gerçek bilgileri yanlıştan ayırmanın zorluğu nedeniyle bu durumun bir infodemiyi ortaya çıkardığını duyurmuştur.

Bununla birlikte, pandemi döneminde COVID-19 virüsüyle ilgili medyada yer bulan yalan haber içerikleri, bireylerde ciddi sağlık sorunlarına sebebiyet vermesi bakımından ayrı bir önem taşımaktadır. Özellikle dijital ortamda birincil tanıdıkların ağzından aktarıldığı ifade edilen içerikler, kullanıcıları yanlış yönlendirerek, hem hastalıktan korunmak için alınabilecek önlemler hem de tedavi sürecinde yapılması gerekenler hakkında yanlış uygulamalara neden olabilmektedir. Ayrıca yukarıda da değinildiği üzere, savaş ya da pandemi gibi büyük toplumsal sorunların deneyimlendiği ve bu sorunlar hakkında çeşitli komplo teorilerinin de kolaylıkla üretilebildiği dönemler, yalan haber içeriklerini beslemektedir (Tandoc vd., 2018). Bu kapsamda Ceron ve arkadaşları (2021, s.2), belirsizlikler ve korkularla dolu kritik bu dönemde kök salan sosyal medya ağlarının, COVID-19 krizinin sömürülerek sorun hakkında aşırı miktarda bilgi üretilmesini olanaklı kıldığının altını çizmektedir.

\section{COVID-19 Așısı ve Yalan Haber}

COVID-19 virüsünün yayılımının engellenebilmesi için aşı çalışmalarının başlamasıyla birlikte, aşıların içeriği, üretim süreci, nasıl uygulanacağı gibi konular hakkındaki haber içerikleri de artmıştır. Aşı haberlerine yönelen bu ilgi, aşının 
niteliği ve yan etkilerini konu alan yalan haber içeriklerindeki artışı da beraberinde getirmiştir. Çoğunlukla komplo teorilerini içeren bu yalan haber içeriklerinden bazıları şöyle sıralanabilir: Aşı aracııı̆ıyla çip takılacağı, aşının Türkler üzerinden daha çok yan etkisinin olduğu, kısırlık yaptığı, DNA'da değişikliğe neden olduğu, aşının yüz felci yaptığı, aşının ölüme sebebiyet verdiği, Avrupa ülkelerinde uygulanan aşıların virüse karşı daha etkili olduğu gibi. Özellikle aşı çalışmalarının başladığı ilk dönemlerde COVID-19 virüsünün bir biyolojik silah olduğu ve aşı çalışmalarına katılan deneklerin hayatını kaybettiğine ya da çok ciddi yan etkilerle karşılaştıklarına ilişkin bilgiler sosyal medya ve WhatsApp üzerinden yoğun olarak paylaşılan içerikler olmuştur (Geldsetzer, 2020; Pennycook vd., 2020). Bill Gates'in insanları kontrol edebilmek için aşı yaptıranlara çip yerleştireceği ise, bu süreçte gündeme gelen bir diğer konu olmuştur. Hatta aşıyla çip takılacağı, siyasetçiler tarafından da dile getirilmiş, Rus Komünist partisi başkanı, sözde "küreselcilerin" COVID-19'a karşı zorunlu aşılama bahanesiyle zamanla başvurabilecekleri gizli bir kitlesel çip implantasyonunu desteklediklerini iddia etmiş, Amerika'da Roger Stone, Bill Gates ve diğerlerinin virüsü insanlara mikroçip takmak için kullandıklarını ileri sürmüştür. Yine Amerika'da konuyla ilgili gerçekleştirilen anket sonuçları, katılımcıların \%28'inin Bill Gates'in insanlara mikroçip yerleştirebilmek için aşıyı kullanmak istediğine inandıklarını göstermektedir (Goodman ve Carmichael, 2020).

COVID-19 aşısı ve yalan haber arasındaki ilişkiye odaklanan çok sayıda çaIışma (Catalan-Matamoros ve Elias, 2020; Loomba vd., 2021; Marco-Franco vd., 2021; Roozenbeek vd., 2020; Sallam vd., 2021), aşı hakkında komplo teorileri içeren haber içerikleriyle karşılaşan bireylerin aşı olma niyetlerinin olumsuz etkilendiğini ortaya koymaktadır. Yalan haberi fark edebilen bireylerin ise, COVID-19 aşısı kabulü olumsuz etkilenmemektedir (Montagni vd., 2021). Bu bakımdan, bireylerin aşının yan etkilerine dair geleneksel ve dijital medyada karşılaştıkları gerçek dışı bilgilerin aşının niteliğine ilişkin düşünceleri ve aşı yaptırma kararları üzerinde doğrudan belirleyiciliğinin olduğunu söylemek mümkündür. Diğer yandan, aşı kabulüne ilişkin tutumlarının durağan olmadığını, aşı tutumunun sahip olunan anlık bilgiye, duygu durumuna ve hastalığın algılanan riskine bağı olarak farklılaştığını da eklemek gerekmektedir (Loomba vd., 2021). Bu nedenle yalan haber içeriklerinin olumsuz etkisinin giderilebilmesi için, güvenilir bulunan bilim insanları ve sağlık uzmanları tarafından kanıta dayalı bilgi akışı sürekli olarak kamuya duyurulmalıdır (de las Heras-Pedrosa vd, 2020; Newman vd., 2021). Çünkü bireyler, COVID-19 aşısına sağlık otoritelerinin açıklamalarıyla uyumlu olarak güvenmeye daha yatkındır (Roozenbeek vd., 2020; Romer ve Jamieson, 2020). Dolayısıyla bu süreçte bireylerin hangi sağlık otoritelerinin açıklamalarını öncelikli olarak takip ettiği, COVID-19 aşısı hakkındaki bilgiyi nereden/kimlerden aradığı, hangi mecralarda karşılaştığı bilgiye öncelikli olarak güvendiği ya da bu bilgiyi nasıl teyit ettiği oldukça önem taşımaktadır.

\section{Amaç ve Yöntem}

Çalışma, Türkiye'de COVID-19 aşııının uygulanmaya başlanması süreci öncesinde, yüksek eğitim düzeyine sahip bireylerin COVID-19 aşısı hakkındaki 
haber içeriklerine dair düşüncelerinin belirlenmesi ve söz konusu haberleri takip etme, güvenme, teyit etme, önem verme eğilimlerinin ortaya koyulması amacını taşımaktadır. Bu amaçtan ve yukarıda yer verilen literatür taramasından hareketle, çalışma, aşağıdaki şu sorulara yanıt aramaktadır:

AS1: Yüksek eğitim düzeyine sahip bireyler, COVID-19 aşısıyla ilgili gelişmeleri öncelikli olarak hangi kanallardan takip etmekte ve takip ettikleri bu kanallarda karşılaştıkları haber içeriklerinde yer verilen hangi aşı isimlerini hatıllamaktadır?

AS2: Yüksek eğitim düzeyine sahip bireyler, aşının olumsuz etkilerine dair karşılaştıkları haber içeriklerinden hangisi/hangilerinin yalan olabileceğini düşünmektedir?

AS3: Yüksek eğitim düzeyine sahip bireyler, medyada COVID-19 aşısıyla ilgili karşılaştıkları haber içeriklerini güvenilir bulmakta mıdır? Bireylerin aşı haberi içeriklerine güvenme eğilimi, söz konusu haber içeriğinin yer aldığı mecra (geleneksel medya, sosyal medya) ya da içeriği aktaran haber kaynağına (Sağlık Bakanı, bireyin sosyal çevresi) bağı olarak farklılaşmakta mıdır? Bireyler bu haberleri hangi biçimde (farklı kaynakları karşılaştırma, sağlık uzmanına danışma) teyit etmektedir?

AS4: Yüksek eğitim düzeyine sahip bireylerin, COVID-19 aşısıyla ilgili geleneksel ve dijital medyada yer alan tartışmalar (aşı karşıtı haberler/politik söylemler, ülkelerin aşı tercihi, aşıya erişim olanağı, aşının olumsuz etkileri) hakkındaki tutumları nelerdir?

Yukarıdaki araştırma sorularını cevaplayabilmek amacıyla, soru formu araclığıyla betimsel yönteme dayalı bir alan araştırması gerçekleştirilmiştir. Çalışmada, Türkiye'de COVID-19 aşısının uygulanmaya başlanmasından önce, bireylerin aşı hakkındaki yalan haberlere yönelik tutumlarının ölçümlenmesi hedeflenmiştir. Araştırmanın gerçekleştirildiği bu dönemde, dünyadaki vaka sayısı 441.662 iken; ölüm sayısı 13.793; en az bir doz aşılanma oranı \%0,84 iken; iki doz aşılanma oranı \%0,32'dir. Türkiye'de ise, tek doz aşılanma oranı \%3,61 iken; iki doz aşılanma oranı \%0,4'tür (Ritchie vd., 2021). Türkiye'deki ilk aşı uygulaması 13 Ocak 2021 tarihinde gerçekleştirilmiş ve Sağlık Bakanı Fahrettin Koca'ya Sinovac (CoronaVac) uygulanmıştır (Usul, 2021).

Çalışmanın evreni, Türkiye'de yaşayan 18 yaşından büyük bireyler olarak belirlenmiştir. Bununla birlikte, konuyla ilgili çalışmalar (Chen vd., 2015; Hossova, 2018; Pop ve Ene, 2019) incelendiğinde, bireyin eğitim düzeyinin, geleneksel ve dijital medyada yer alan yalan haber içeriklerinin kabulü, reddi ve yayılım hızıyla doğrudan ilişkili olduğu; ancak diğer yandan eğitim düzeyi ile aşı kararsızlığı ilişkisinin ülkelerin sosyo-ekonomik ve kültürel yapısına bağlı olarak da değişkenlik gösterdiği görülmektedir. Buna göre Çin, Lübnan, İsrail, Bangladeş ve Amerika gibi ülkelerde yüksek eğitim düzeyine sahip bireylerin daha fazla aşı kararsızlığı yaşadığı belirtilirken (Du vd., 2020; Kricorian vd., 2021; Larson, 2014); Ingiltere, 
Italya, Rusya, Fransa, Yunanistan, Hollanda, Nijerya ve Pakistan gibi ülkelerde düşük eğitim düzeyine sahip bireylerin daha fazla aşı kararsızlığı yaşadığından bahsedilmektedir (Holeva vd., 2021; Larson, 2014; Lazarus vd., 2020; Robertson vd., 2021; Schwarzinger vd., 2021). Bu çerçevede değerlendirildiğinde, eğitim düzeyinin aşı kararsızlığı ya da reddi üzerinde önemli bir belirleyiciliğinin olduğu açıkça ortadadır. Türkiye özelinde gerçekleştirilen az sayıda çalışma incelendiğinde ise, aşı kararsızlığı ve reddine eğitim düzeyi yüksek bireylerde daha çok rastlandığı (Özceylan vd., 2020); söz konusu kararsızlığın COVID-19 aşısı için de geçerli olduğu (ïkiışık vd., 2021; Kılıç vd., 2021) görülmektedir. Bu çerçevede ele alındığında, çalışma kapsamında yüksek eğitim seviyesine sahip bireylere ulaşımasının, yalan haber içeriklerine ilişkin daha yüksek düzeyde farkındalığı olması beklenen bireylerin söz konusu içeriklere bağlı olarak COVID-19 aşısına yönelik nasıl bir tutuma sahip olduklarının belirlenebilmesi açısından önem taşıyacağı düşünülmüş ve çalışma yüksek eğitim düzeyine sahip bireylerle gerçekleştirilmiştir.

Belirlenen evren içerisinde örnekleme dahil edilecek bireylerin seçiminde ise, basit rastlantısal örneklem kullanılmıştır. Örneklem büyüklüğüne ilişkin bir hatayla karşılaşmamak adına ise, belirlenen evren içerisinden ulaşılan katılımcıların Türkiye nüfusunu temsil eder bir düzeyde olmasına dikkat edilmiştir. Buna göre Türkiye'deki yüksek eğitim mezunu bireylerin oranı göz önünde bulundurulduğunda (TÜiK, 2019), çalışma kapsamında ulaşılan örneklemin temsil düzeyinin \%98 güvenirlilik düzeyinde \%3,52'lik bir hata payına sahip olduğunu söylemek mümkündür.

Hazırlanan soru formu, dört bölümden oluşmaktadır. İlk bölümde katılımcıların demografik özelliklerini (cinsiyet, yaş, eğitim düzeyi) belirlemeye ilişkin sorular, ikinci bölümde aşı ile ilgili gelişmeleri hangi düzeyde ve hangi kanallardan takip ettiklerini belirlemeye yönelik sıralama sorularına yer verilmiştir. Soru formunun üçüncü ve dördüncü bölümlerinde ise, $5^{\prime}$ li likert ölçeğinden (kesinlikle katılıyorum, katılıyorum, fikrim yok, katılmıyorum, kesinlikle katılmıyorum) yararlanılmıştır. Üçüncü bölümdeki likert ölçeğinde, bireylerin COVID-19 aşısıyla ilgili bilgi alma ve teyit etme eğilimlerini belirlemeye yönelik ifadelere; dördüncü bölümde ise, bireylerin COVID-19 aşısı hakkında medyada yer alan tartışmalara ilişkin tutumlarını belirlemeye yönelik ifadelere yer verilmiştir. Likert ölçeğinde bulunan ifadelerin yazımı ise, hem çalışma kapsamında gerçekleştirilen literatür taraması çerçevesinde yeni ifadelerin eklenmesi hem de konuyla ilgili önceki benzer çalışmalarda (Argüt vd., 2016; Loomba vd., 2021; Solmaz vd., 2013; Türkay vd., 2017) kullanılan likert ölçeği ifadeleri incelenip, düzenlenerek soru formuna dahil edilmesi şeklinde gerçekleşmiştir.

Son hali verilen soru formu, dijital ortamda öncelikle 60 katılımcıya uygulanmış, bu aşamada herhangi bir sorunla karşılaşılmamış; 11.02.2021-24.02.2021 tarihleri arasında toplamda 1264 katılımcının yanıtladığı soru formunun 1092'si analiz edilmeye uygun görülmüştür. Katılımcıların soru formuna verdikleri yanıtların güvenilirlik düzeyine bakıldığında, Cronbach Alpha sayısının 0,840 düzeyinde 
yüksek güvenilirliğe sahip olduğunu söylemek mümkündür. Soru formuna verilen yanıtların değerlendirilmesinde ise, öncelikle verilen yanıtlar kontrol edilerek, kodlanmış; sonrasında işlenmeye hazır hale getirilen veriler SPSS 22.0 programına aktarımıştır. Araştırma sorularının cevaplanabilmesi için gerçekleştirilen betimsel analizler de yine aynı program üzerinden elde edilmiştir.

\section{Bulgular}

Katılımcıların demografik özellikleri incelendiğinde, çalışmada yer alan bireylerin \%31,5'i (344 kişi) kadın, \%68,5'i (748 kişi) erkek; \% 7,4'ü (81 kişi) 18-25, \%59'u (644 kişi) 26-35, \%19,4'ü (212 kişi) 36-45, \%12'si (131 kişi) 46-55, \%1,9'u (21 kişi) 55-64, \%0,3'ü (3 kişi) 65 üstü yaş aralığında; \% 85,2'si (930 kişi) lisans, \%14,8'i (162 kişi) lisansüstü program mezunudur. Söz konusu demografik bulgulara göre, çalışmada yer alan katılımcıların 26-55 yaş aralığında lisans mezunu bireyler açısından yoğunluk gösterdiğini söylemek olanaklıdır. Bununla birlikte, geleneksel ve dijital medyada COVID-19 aşısıyla ilgili gelişmeleri katılımcıların \%10,2'sinin düşük, \%59,7'sinin (652 kişi) orta, \%30,1'inin (yüksek) düzeyde takip ettikleri görülmektedir.

Katılımcıların COVID-19 aşısında ilişskin gelişmeleri takip ettikleri öncelikli haber kaynaklarını şöyle sıralamak mümkündür:

Tablo 1: Katılımcıların COVID-19 aşısına ilişkin gelişmeleri takip ettikleri haber kaynakları

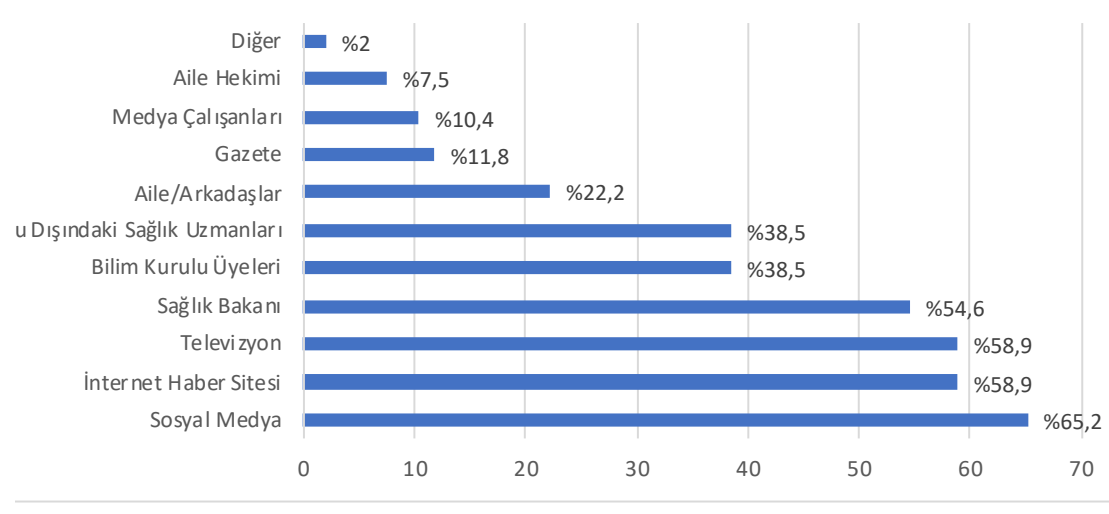

Tabloya göre, katılımcılar COVID-19 aşısına ilişkin gelişmeleri öncelikli olarak sosyal medya üzerinden takip etmektedir. İkinci sırada, internet haber sitesi ve televizyon gelmekte; üçüncü sırada Sağlık Bakanı'nın açıklamaları yer almaktadır. Katılımcıların COVID-19 aşısına ilişkin gelişmeleri takip ettiklerini belirttikleri diğer kaynaklar ise sırasıyla şöyledir: Bilim kurulu üyelerinin açıklamaları, bilim ku- 
rulu dışındaki sağlık uzmanlarının açıklamaları, aile ve arkadaşlar, gazete, medya çalışanları ve aile hekimi.

Katılımcıların aşı gelişmelerini takip ettikleri bu haber kaynaklarında karşılaştıkları haber içeriklerinde bahsedilen COVID-19 aşılarından hangilerinin isimlerini hatırladıkları da sorulmuştur. Buna göre, katılımcıların söz konusu haber içerikleri üzerinden hatırladıklarını ifade ettikleri aşı isimleri aşağıdaki gibidir:

Tablo 2: Katılımcıların karşılaştıkları haber içerikleri üzerinden hatırladıkları aşı isimleri

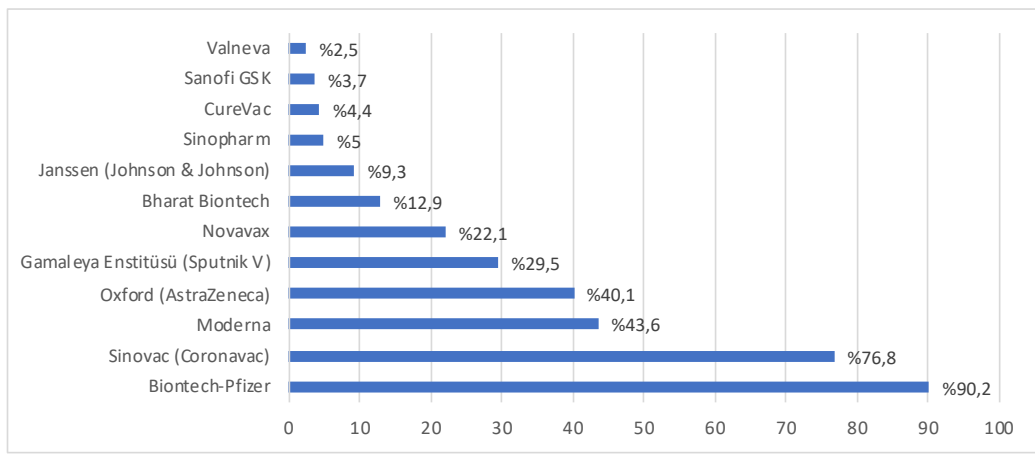

Tabloya göre, katılımcıların en yüksek düzeyde haberdar oldukları aşının Biontech-Pfizer olduğu görülmekte, bunu Sinovac (CoronaVac) aşısı takip etmektedir. Katılımcıların isminden haberdar olduklarını belirttikleri diğer aşı isimleri ise, sırasıyla şöyledir: Moderna, Oxford, Gamaleya Enstitüsü, Novavax, Bharat Biontech, Janssen, Sinopharm, CureVac, Sanofi GSK, Valneva.

Katılımcıların aşının olumsuz etkilerine dair medyada karşılaştıkları ve yalan haber olabileceğini düşündükleri içerikler ise, aşağıdaki gibidir:

Tablo 3: Aşının olumsuz etkilerine dair yalan haber olabileceği düşünülen içerikler

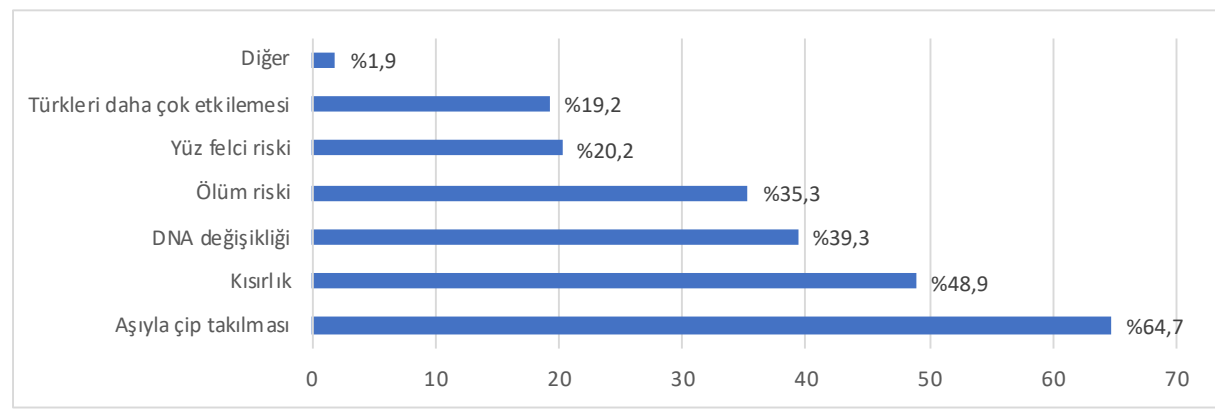


Buna göre, katılımcıların geleneksel ve dijital medyada aşının olumsuz etkilerine dair karşılaştıkları ve en yüksek düzeyde yalan haber olduğunu düşündükleri içerik, COVID-19 aşısı aracııı̆ıyla bireylere çip takılması olmuştur. İkinci sırada, kısılık riski gelmekte; bunu üçüncü sırada aşının DNA değişikliği yaptığı haberleri takip etmektedir. Katılımcılar tarafından yalan haber olduğu düşünülen diğer haber içerikleri ise, sırasıyla şöyle olmuştur: ölüm riski, yüz felci riski, aşının Türkleri daha çok olumsuz etkilediği.

Tablo 4: Geleneksel ve dijital medyada COVID-19 aşısıyla ilgili bilgiye güvenme ve teyit etme oranları

\begin{tabular}{|c|c|c|c|}
\hline $\begin{array}{l}\text { Geleneksel ve dijital medyada COVID-19 asısıla ilgili } \\
\text { karpalasılan bilgiye gũveame ve teyit etme }\end{array}$ & Ortalama & $\begin{array}{c}\text { Standart } \\
\text { Sapma }\end{array}$ & $\mathbf{N}$ \\
\hline Modyadaki ą̧ haberkerini gûvenilir bulmuyorum. & 3,19 & 1,349 & 1092 \\
\hline $\begin{array}{l}\text { Medyada yer verilen aşı haberlerinin yeterince bilgi verici } \\
\text { olmadığina dü̧ünûyorum. }\end{array}$ & 3,26 & 1,412 & 1092 \\
\hline $\begin{array}{l}\text { Sosyal medyada aşı ile ilgili çok fazla yalan haber olduğunu } \\
\text { đūşūnūyorum. }\end{array}$ & 3,49 & 1,427 & 1092 \\
\hline $\begin{array}{l}\text { Aşı ile ilgili sosyal medyada sōylenenlere õnem vermek } \\
\text { gerektiģinin düsünûyorum. }\end{array}$ & 2,67 & 1,334 & 1092 \\
\hline 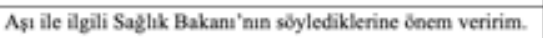 & 3,22 & 1,397 & 1092 \\
\hline 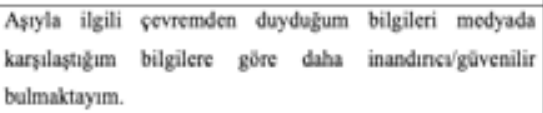 & 2,54 & 1,257 & 1092 \\
\hline $\begin{array}{l}\text { COVID-19 aşsılyla ilgili gelişmeleri, farklı kaynaklardan } \\
\text { bilgileri karsılasttrarak takip etmekteyim. }\end{array}$ & 3,29 & 1,322 & 1092 \\
\hline 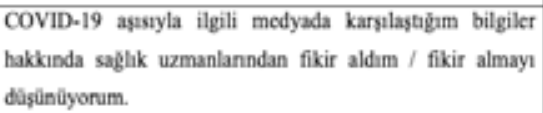 & 3,26 & 1,316 & 1092 \\
\hline
\end{tabular}

Bireylerin geleneksel ve dijital medyada COVID-19 aşısıyla ilgili karşılaştıkları bilgiye güvenme eğilimlerine bakıldığında; katıımcıların medyadaki aşı haberlerinin güvenilir bulmadıkları (Ort. 3,19; s.s.1,349), medyada yer alan aşı haberlerinin yeterince bilgi verici olmadığını düşündükleri (Ort.3,26; s.s.1,412), sosyal medyada aşı ile ilgili çok fazla yalan haber olduğuna inandıkları (Ort.3,49; s.s.1,427), aşı ile ilgili sosyal medyada söylenenlere önem vermek gerektiğine düşük düzeyde katılıkları (Ort.2,67; s.s.1,334), Sağlık Bakanı'nın aşıyla ilgili söylediklerine önem verdikleri (Ort. 3,22; s.s. 1,397) ve aşıyla ilgili çevrelerinden duydukları bilgileri medyada karşılaştıkları bilgilere göre daha düşük düzeyde inandırıcı/güvenilir buldukları (Ort. 2,54; s.s. 1,257) görülmektedir. 
Tablo 5: COVID-19 aşısıyla ilgili geleneksel ve dijital medyada yer alan tartışmalara ilişkin katııımcı tutumları

\begin{tabular}{|c|c|c|c|}
\hline 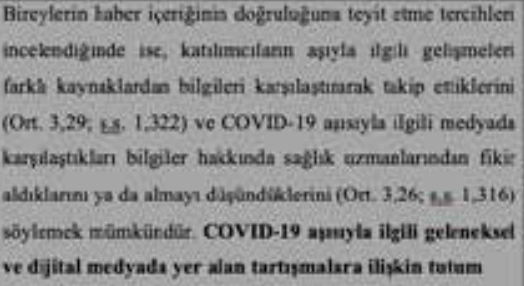 & Ortalama & $\begin{array}{l}\text { Standart } \\
\text { Sagma }\end{array}$ & $\mathrm{N}$ \\
\hline 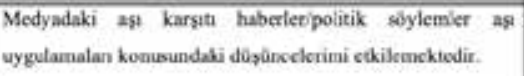 & 2,60 & 1.286 & 1092 \\
\hline $\begin{array}{l}\text { Sosyal modyadaki COVID-19 aqiss tartignalan ve aqu kargati } \\
\text { haberler benim aşya iliskin tutumu etkilemektodir. }\end{array}$ & 2,56 & 1,296 & 1092 \\
\hline $\begin{array}{l}\text { Amerika ve Avrupa alkelerinin tercih cttiói aqularin daha iyi } \\
\text { oldugunu dissuinâyorum. }\end{array}$ & 2,90 & 1,306 & 1092 \\
\hline 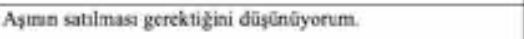 & 2,03 & 1,187 & 1092 \\
\hline Türkye'nin diger aşlan da alması gerektiğini düpüelyonums & 3,33 & 1,380 & 1092 \\
\hline 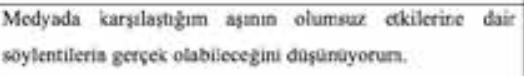 & 2,68 & 1.234 & 1092 \\
\hline
\end{tabular}

Bireylerin COVID-19 aşısıyla ilgili geleneksel ve dijital medyada yer alan tartışmalara ilişkin tutumları incelendiğinde, katılımcıların medyada karşılaştıkları aşı karşıtı haberlerin ve politik söylemlerin aşı uygulamaları hakkındaki düşüncelerini etkilediğini düşünmedikleri (Ort. 2,60; s.s. 1,286), sosyal medyadaki COVID-19 aşısı tartışmaları ve aşı karşıtı haberlerin tutumlarını etkilediğine inanmadıkları (Ort. 2,56; s.s. 1,296), Amerika ve Avrupa ülkelerinde tercih edilen aşıların daha iyi olduğunu yönünde bir düşüncelerinin olmadığı (Ort. 2,90; s.s. 1,306), aşının satılması gerektiği görüşüne katılmadıkları (Ort. 2,03; s.s. 1,187), medyada aşının olumsuz etkilerine dair karşılaştıkları söylentilerin gerçek olabileceğini düşünmedikleri (Ort. 2,68; s.s. 1,234) ve Türkiye'nin diğer aşıları da alması görüşünü destekledikleri (Ort. 3,33; s.s. 1,380) görülmektedir.

\section{Sonuç ve Değerlendirme}

Türkiye'de COVID-19 aşısının uygulanmaya başlanması süreci öncesinde, bireylerin aşı hakkındaki yalan haber içeriklerine ilişkin düşüncelerinin belirlenmesi ve söz konusu haberleri takip etme, güvenme, teyit etme, önem verme eğilimlerinin ortaya koyulması amacını taşıyan çalışma kapsamında, betimsel bir alan araştırması gerçekleştirilmiştir. Çoğunluğu COVID-19 aşısına dair gelişmeleri orta ve yüksek düzeyde takip ettiğini belirten katıımcıların, öncelikli olarak sosyal medyadan yararlandıkları görülmektedir. Sosyal medyadan sonra, takip 
edilen diğer öncelikli kanallar ise, sırasıyla, haber siteleri, televizyon içerikleri ve Sağıı Bakanı'nın konuyla ilgili açıklamaları olmuştur. Bu bakımdan katıımcıların COVID-19 aşısıyla ilgili bilgiyi öncelikli olarak sosyal medya, haber siteleri, televizyonda yayınlanan aşı içerikleri ve Sağlık Bakanı'nın açıklamaları üzerinden aradıklarını söylemek mümkündür. Katıımcıların bu içerikler üzerinden ismini en çok hatırladıkları aşının ise, Biontech-Pfizer olduğu görülmekte; Türkiye'de uygulanmaya ilk başlanan aşı olan Sinovac (CoronaVac) ise ikinci sırada yer almaktadır. Bu kapsamda ele alındığında, Sinovac (CoronaVac) aşısından haberdar olduğunu belirten daha az katılımcı olması, COVID-19 aşıSı gelişmelerinin takibi noktasında katıımcıların düşük farkındalığını göstermesi bakımından önem arz etmektedir. Ek olarak, katılımcıların hatırladıkları aşı isimleriyle ilgili karşılaştıkları ve en yüksek düzeyde gerçek dışı olduğunu düşündükleri haber içeriklerinin başında aşıyla çip takılacağı gelmektedir. Bu çerçevede değerlendirildiğinde, katılımcılar her ne kadar ülkede uygulanmaya başlanan Sinovac (CoronaVac) aşısından Biontech-Pfizer aşısına nazaran daha düşük oranda haberdar olsalar da, çoğunluğunun adı geçen bu aşılar aracılığıyla çip takılacağı hakkındaki haber içeriklerinin gerçeği yansıtmadığının ayırdında olduklarını belirtmek yanlış olmayacaktır.

Katıımcılar medyada yer alan aşı haberlerinin genel olarak güvenilir olduğunu düşünmekte, ancak bu haberleri yeterince bilgi verici bulmamaktadırlar. Ayrıca aşı hakkındaki bilgiyle hangi mecrada karşılaşıldığının bireyin o bilgiye olan güveni üzerinde de belirleyici olduğunu söylemek mümkündür. Her ne kadar en fazla yararlanılan bilgi kaynağı sosyal medya olsa da katıımcıların sosyal medyada aşı hakkında çok fazla yalan haber olduğunu düşündükleri ve bu nedenle söz konusu mecrada aşıyla ilgili söylenenlere çok önem vermemek gerektiğine inandıkları görülmektedir. Bu bakımdan değerlendirildiğinde, sosyal medyanın bilgi almak için yüksek oranda tercih ediliyor olmasını erişimi en kolay ve ergonomik mecra olmasıyla açıklamak yanlış olmayacaktır. Bireyler, eriştikleri bilginin doğasından kuşku duysalar da bu durum sosyal medya içeriklerini takip edilmesini engellememektedir.

Yine aşı hakkında Sağlık Bakanı'nın söylediklerine yüksek oranda önem verdiklerini belirten katıımcıların, aşıyla ilgili çevrelerinden duydukları bilgileri medyadaki bilgilere göre daha güvenilir bulmadıkları da görülmektedir. Bu çerçevede değerlendirildiğinde, bireylerin aşı hakkındaki bilgiyi kimden ya da nereden duyduklarının o haber içeriğine güvenme düzeyleri üzerinde belirleyici olduğunu; bu süreçte öncelikle Sağlık Bakanı'nın açıklamalarına önem verildiğini, çevreden duyulan bilgilerin medyada karşılaşılanlara nazaran daha güvenilir içerikler olarak algılanmadığını belirtmek olanaklıdır. Dolayısıyla, mecra fark etmeksizin Sağlık Bakanı'nın aşı hakkındaki açıklamalarının hem katıımcılar tarafından öncelikli olarak takip edildiği hem de bu açıklamalara güven duyulduğu çalışmanın önemli sonuçlarından biridir. Bu kapsamda ulaşılan çalışma sonuçlarının, Amerika (Fridman vd., 2020) ve Çin (Lu vd., 2021) gibi ülkelerde gerçekleştirilen COVID-19 salgını süresince bireylerin en çok resmi devlet kanallarından gelen açıklamalara güven duyduklarını gösteren araştırma sonuçlarıyla tutarlık gösterdiği söylenebilir. Ayrı- 
ca COVID-19 aşısı hakkında kişilerarası ilişkiler aracıı̆ı̆ıla edinilen bilginin, geleneksel ve sosyal medyadan edinilen bilgiye nazaran daha güvenilir bulunmuyor olması da ulaşılan bulgular arasındadır. Erişilen aşı bilgisinin nasıl teyit edildiği incelendiğinde, katılımcıların çeşitli sağlık uzmanlarından bilgi aldıklarını ve aşı gelişmelerini farklı kaynaklardan karşılaştırarak takip ettiklerini ifade ettikleri görülmektedir. Yani bireyler, içeriği hakkında kuşku duydukları haberleri güvendikleri sağlık uzmanlarına doğrudan danışarak ya da konuyla ilgili açıklamalarını dinleyerek ve farklı mecralardaki haber kaynaklarında yer alan bilgilerle karşılaştırarak teyit etmektedirler. Bireylerin aşı haberlerini teyit etme davranışları, yalan haber içerikleri aracılığıyla yanlış yönlendirilmelerinin ve yaşayacakları sağlık endişesinin engellenebilmesi açısından oldukça önem taşımaktadır. Bu çerçevede değerlendirildiğinde, katılımcıların sosyal medyada karşılaştıkları içeriklerin daha yüksek düzeyde gerçek dışı olabileceğini düşünmelerinin ve aşı hakkındaki bilgilerini sağlık uzmanlarına danışarak ya da farklı mecralarda karşılaştırarak teyit etmelerini katıımcıların yüksek eğitim seviyesine sahip olmalarıyla açıklamak mümkündür. Çünkü ilgili çalışmalar, COVID-19 aşısı hakkında yalan haber içeriklerine inanma eğiliminin eğitim seviyesiyle ilişkili olduğunu (Kreps ve Kriner, 2020) ve yine eğitim düzeyiyle bağlantılı yüksek sağlık okuryazarlığına sahip bireylerin sağlık bilgisi arama çabalarının daha fazla olduğunu (Kılanç ve Öztürk, 2020) göstermektedir. Bu bakımdan, bireylerin medyada karşılaştıkları ve gerçekliğinden emin olmadıkları aşı gelişmelerini hem sağlık uzmanları hem de farklı mecralarda yer alan içerikler üzerinden karşılaştırarak, teyit etmelerinin eğitim düzeyleriyle ilişkilendirmek olanaklıdır. Bu kapsamda, ulaşılan çalışma sonuçlarının İtalya'da çoğunluğu yüksek eğitim seviyesine sahip bireylerle gerçekleştirilmiş benzer çalışma (Falcone ve Sapienza, 2020) sonuçlarıyla da tutarlıık gösterdiği görülmektedir. Ayrıca bu durum bireylerin aşı hakkındaki yalan haber içerikleri nedeniyle yaşayacakları sağıık kaygısının önüne geçebilmeleri açısından da önemlidir.

Yukarıda da değinildiği üzere Loomba ve arkadaşları (2021) bireylerin COVID-19 aşısına yönelik tutumlarının sabit olmadığından aşı tutumunun sahip olunan anlık bilgiye, duygu durumuna ve hastalığın algılanan riskine bağlı olarak farklılaşabileceğinden bahsetmektedir. Bu kapsamda ele alındığında, bireylerin COVID-19 aşısı hakkında geleneksel ve dijital medyada yer alan tartışmalara ilişkin düşünce ve tutumlarının da belirlenmesi oldukça önem taşımaktadır. Buna göre katılımcılar, medyada karşılaştıkları aşı karşııı haberlerin ve politik söylemlerin aşı uygulamaları hakkındaki düşüncelerini etkilediğini düşünmemekte, Amerika ve Avrupa ülkelerinde tercih edilen aşıların daha iyi olduğuna inanmamakta, sosyal medyadaki COVID-19 aşısı tartışmalarının aşıya ilişsin tutumlarını etkilemediğini belirtmekte, aşının satılması gerektiği görüşüne katılmamakta, medyada aşının olumsuz etkilerine dair karşılaştıkları söylentilerin gerçek olabileceğini düşünmemektedirler. Bu bakımdan katıımcıların medyadaki aşı uygulamaları hakkındaki alternatif söylemlerin büyük bir çoğunluğuna katılmadıklarını söylemek yanlış olmayacaktır. Katılımcıların desteklediği tek tartışma konusu, Türkiye'nin diğer aşıları da alması gerektiği olmuştur. 
Sonuç olarak, tüm dünyada COVID-19 virüsünün önlenebilmesi amacıyla başlayan aşı çalışmalarına yönelen ilgi, geleneksel ve dijital medyada konuyla ilgili yoğun içerik üretimini de beraberinde getirmiş, bu süreçte karşılaşılan yalan haberler bireylerin sağlıklarıyla ilgili kararları üzerinde belirleyici rol oynaması bakımından önemli risk unsurlarına dönüşmüştür. Bu bakımdan yalan haber içerikleri ve bireylerin COVID-19 aşısına ilişkin tutumları arasındaki ilişkiye odaklanan sonraki çalışmaların da, toplumun medya ve sağlık okuryazarlığının geliştirilebilmesi sürecinde oldukça önemli bir rol üstleneceğini belirtmek gerekmektedir. Ayrıca bu çalışmanın yüksek eğitim düzeyine sahip bireylerle gerçekleştirildiği ve erişilen örneklemde 60 yaş üzeri katılımcı sayısının da sınırı kaldığı hatırlatılmalıdır. Dolayısıyla, farklı örneklem grupları üzerinden yalan haber içeriklerine bağlı olarak aşı tutumunun nasıl şekillendiğini inceleyen yeni çalışmalara da intiyaç duyulmaktadır.

\section{Kaynakça}

Argüt, N., Yetim, A. ve Gökçay, G. (2016). Aşı Kabulünü Etkileyen Faktörler. Çocuk Dergisi, 16(1-2), 16-24.

Beschloss, M. (2002) Dividing the Spoils. Smithsonian Magazine. Erişim 23 Mart 2021 https://cutt.ly/KcQ3wr0

Boberg, S., Quandt, T., Schato-Eckrodt, T. ve Frischlich, L. (2020) Pandemic Populism: Facebook Pages of Alternative News Media and the Corona Crisis - A Computatonal Content Analysis. ArXiv E-Prints, 2004.02566. Erişim 5 Nisan 2021 https://cutt.ly/scWUbsv

Carrieri, V., Madio, L. ve Principe, F. (2019). Vaccine Hesitancy and (Fake) News: Quasi-experimental Evidence from Italy. Health Economics, 28(11), 1377-1382.

Catalan-Matamoros, D. ve Elías, C. (2020). Vaccine Hesitancy in the Age of Coronavirus and Fake News: Analysis of Journalistic Sources in the Spanish Quality Press. International Journal of Environmental Research and Public Health, 17(21), 8136-8151.

Ceron, W., de-Lima-Santos, M.F. ve Quiles, M.G. (2021). Fake News Agenda in the Era of COVID-19: Identifying Trends through Fact-checking Content. Journal of Online Social Networks and Media, 21, 100116.

Chen, X., Sin, S.C.J., Theng, Y.L. ve Lee, C.S. (2015). Why Students Share Misinformation on Social Media: Motivation, Gender, and Study-level Differences. The Journal of Academic Librarianship, 41(5), 583-592.

de las Heras-Pedrosa, C., Rando-Cueto, D., Jambrino-Maldonado, C. ve Paniagua-Rojano, F.J. (2020). Exploring the Social Media on the Communication Professionals in Public Health: Spanish Offical Medical Colleges Case Study. International Journal of Environmental Research and Public Health, 17(13), 48-59.

Dirini, İ. ve Özsu G. (2020). COVID-19 Pandemi Sürecinde Sosyal Medyada Nefret Söylemi Raporu. Z. Özarslan (Ed.), Ankara: Alternatif Bilişim.

Du, F., Chantler, T., Francis, M.R., Sun, F.Y., Zhang, X., Han, K., Rodewald, L., Yu, 
H., Tu, S., Larson, H. \& Hou, Z. (2021). The determinants of vaccine hesitancy in China: A cross-sectional study following the Changchun Changsheng vaccine incident. Vaccine, 38(47), 7464-7471.

Dünya Sağlık Örgütü (2020). Novel Coronavirus (2019-nCoV) Situation Report - 13. Erişim 5 Nisan 2021 https://cutt.ly/lcWYqun

Eberle, H. ve Uhl, M. (2005). The Hitler Book: The Secret Dossier Prepared for Stalin from the Interrogations of Hitler's Personal Aides. New York: Public Affairs

Eguia, H., Vinciarelli, F., Bosque-Prous, M., Kristensen, T. ve Saigí-Rubió, F. (2021). Spain's Hesitation at the Gates of a COVID-19 Vaccine. Vaccines, 9(2), 170.

Erkan, G. ve Ayhan, E. (2018). Siyasal Iletişimde Dezenformasyon ve Sosyal Medya: Bir Doğrulama Platformu Olarak Teyit.Org. Akdeniz İletişim Dergisi, 29, 202-223.

Falcone, R. ve Sapienza, A. (2020). How COVID-19 Changed the Information Needs of Italian Citizens. International Journal of Environmental Research and Public Health, 17, 6988.

Fridman, I., Lucas, N., Henke, D. \& Zigler, C. K. (2020). Association between public knowledge about COVID-19, trust in information sources, and adherence to social distancing: cross-sectional survey. JMIR public health and surveillance, 6(3), e22060.

Geldsetzer, P. (2020). Knowledge and Perxeptions of COVID-19 among the General Public in the United States and the United Kingdom: A Cross-sectional Online Survey. Annals of Internal Medicine, 173(2), 157-160.

Goodman, J. ve Carmichael, F. (2020). Coronavirus: Bill Gates 'microchip' conspiracy theory and other vaccine claims fact-checked. Erişim 8 Nisan 2021 https:// www.bbc.com/news/52847648

Gül-Ünlü, D. \& Kesgin, Y. (2021). Tavşan deliği ve siyasal radikalleşme: YouTube kullanıc önerileri üzerinden bir değerlendirme. A. Aydemir (Ed.). Gelenekselden dijitale siyasal iletişim çalışmaları içinde (67-78). Konya: Eğitim Yayınevi.

Holeva, V., Parlapani, E., Nikopoulou, V.A., Nouskas, I. \& Diakogiannis, I. (2020). COVID-19 vaccine hesitancy in a sample of Greek adults. Psychology, Health \& Medicine, 1-7.

Íkiışık, H., Sezerol, M.A., Taşçı, Y. \& Maral, I. (2021). COVID-19 Vaccine hesitancy: A community-based research in Turkey. International Journal of Clinical Practice, e14336.

Jain, J., Saurabh, S., Goel, A.D., Gupta, M.K., Bhardwaj, P. ve Raghav, P.R. (2021). COVID-19 Vaccine Hesitancy among Undergraduate Medical Students: Results from a Nationwide Survey in India. MedRxiv, Erişim 11 Nisan 2021 https://cutt.ly/Wc4RqUa

Hossova, M. (2018). Fake News and Disinformation: Phenomenons of Post-factual Society. Media Literacy and Academic Research, 1(2): 27-35. 
Kershaw, I. (2001). Hitler, 1936-1945: Nemesis. New York: W. W. Norton \& Company

Kılanç, R. ve Öztürk, Y.E. (2020). Halkın Sağlık Okuryazarlığı Düzeyi ile Sağlık Kaygısı Arasındaki Iliş̧ki. Sosyoloji Araştırmaları Dergisi, 23(2), 214-243.

Kılıç, M., Ustundag-Ocal, N. \& Uslukıııc, G. (2021). The relationship of COVID-19 vaccine attitude with life satisfaction, religious attitude and COVID-19 avoidance in Turkey. Human Vaccines \& Immunotherapeutics, 17(10), 3384-3393.

Kiraz, E. (2019). Sosyal medya ve algı yönetimi: İngiltere'nin Brexit sürecinde sosyal medya dezenformasyonu. Paradoks Ekonomi, Sosyoloji ve Politika Dergisi, 15(1), 1-18. Kremps, S.E. ve Kriner, D. (2020). Medical Misinformation in the COVID-19 Pandemic. SSRN, Erişim 10 Nisan 2021 https://cutt.ly/Dc4RvEP

Kricorian, K., Civen, R. \& Equils, O. (2021). COVID-19 vaccine hesitancy: Misinformation and perceptions of vaccine safety. Human Vaccines \& Immunotherapeutics, 1-18.

Larson, H.J., Jarrett, C., Echersberger, E., Smith, D.M. \& Paterson, P. (2014). Understanding vaccine hesitancy around vaccines and vaccination from a global perspective: A Systematic review of published literature, 2007-2012. Vaccine, 32(19), 2150-2159.

Lazarus, J.V., Ratzan, S., Palayew, A., Gostin, L.O., Larson, H.J., Robin, K., Kimball, S. \& El-Mohandes, A. (2020). Hesitant or not? A global survey of potential acceptance of a COVID-19 vaccine. MedRxiv. Erişim 16 Kasım 2021 https://bit.ly/3njGLDz

Lazer, D., Baum, M., Grinberg, N., Friedland, L., Joseph, K., Hobbs, W. \& Mattsson, C. (2017). Combating fake news: An agenda for research and action. Erişim 18 Kasım 2021 https://bit.ly/3qS435x

Loomba, S., de Figueiredo, A., Piatek, S. J., de Graaf, K. ve Larson, H. J. (2021). Measuring the impact of COVID-19 vaccine misinformation on vaccination intent in the UK and USA. Nature Human Behaviour, 1-12.

Ljungholm, D.P. ve Olah, M.L. (2020). Regulating Fake News Content During COVID-19 Pandemic: Evidence-based Reality, Trustworthy Sources, and Responsible Media Reporting. Review of Contemporary Philosophy, 19, 43-49.

Lu, L., Liu, J., Yuan, Y. C., Burns, K. S., Lu, E. \& Li, D. (2021). Source Trust and COVID-19 Information Sharing: The Mediating Roles of Emotions and Beliefs About Sharing. Health Education \& Behavior, 48(2), 132-139.

MacDonald, N.E. (2020). Oral Health in Canada: Fake News and Science Denier Attacks on Vaccines. What Can You Do?. Canada Communicable Disease Report, 46(1112), 432-435.

Marco-Franco, J.E., Pita-Barros, P., Vivas-Orts, D., Gonzales-de-Julian, S. ve Vivas-Consuelo, D. (2021). COVID-19, Fake News, and Vacciness: Should Regulati- 
on Be Implemented?. International Journal of Environmental Research and Public Health, 18(2), 744-755.

Mas, L. (2020). Bat Soup in China? This Video of a Bat in Broth was Filmed in the Pacific. Observers-France24. Erişim 5 Nisan 2021 https://cutt.ly/Ec4RHUv

McDowra, T. (2018). Ten Deaths and 37 Poison Cases Reported after Children Take the Tide Detergent Pod Challenge. Eparisextra News. Erişim 4 Nisan 2021 https://cutt.ly/Yc4TjMj

Metzger, M.J. (2007) Making Sense of Credibility on the Web: Models for Evaluating Online Information and Recommendations for Future Research. Journal of the American Society for Information Science and Technology, 58(13), 2078-2091.

Montagni, I., Ouazzani-Touhami, K., Mebarki, A., Texier, N., Schück, S. ve Tzourio, C. (2021). Acceptance of a COVID-19 Vaccine is Associated with Ability to Detect Fake News and Health Literacy. Journal of Public Health, fdab028.

Moscadelli, A., Albora, G., Biamonte, M.A., Giorgetti, D., Innocenzio, M., Paoli, S., Lorini, C., Bonanni, P. ve Bonaccorsi, G. (2020). Fake News and COVID-19 in Italy: Results of a Quantitative Observational Study. International Journal of Environmental Research and Public Health, 17(16), 5850.

Murphy, J., Vallieres, F., Bentall, R.P., Shevlin, M., McBride, O., Hartman, T.K., McKay, R., Bennett, K., Mason, L., Gibson-Miller, J., Levita, L., Martinez, A.P., Stocks, T.V., Karatzias, T. ve Hyland, P. (2021). Psychological Characteristics Assosiated with COVID-19 Vaccine Hesitancy and Resistance in Ireland and United Kingdom. Nature Communications, 12(29), 1-15.

Newman, N., Fletcher, R., Kalogeropoulos, A., Levy, D.A. ve Nielsen, R.K. (2017). Reuters Institute Digital News Report, 2017. Erişim 8 Nisan 2021 https://cutt.ly/qcZrVLy

Özceylan, G., Toprak, D. \& Esen, E.S. (2020). Vaccine rejection and hesitation in Turkey. Human Vaccines \& Immunotherapeutics, 16(5), 1034-1039.Palade, I. ve Balaban, D.C. (2020). An Analysis of COVID-19-Related Fake News from Romania. A Pilot Qualitative Study. Journal of Media Research, 13(2), 27-43.

Pariser, E. (2011). The filter bubble: How the new personalized web is changing what we read and how we think. New York: Penguin Publishing.Pennycook, G., McPhetres, J., Zhang, Y., Lu, J.G. ve Rand, D.G. (2020). Fighting COVID-19 Misinformation on Social Media: Experimental Evidence for a Scalable Accuracy-Nudge Intervention. Psychological Science, 31(7), 770-780.

Pop, M.I. ve Ene, I. (2019). Influence of Educational Level on the Spreading of Fake New Regarding the Energy Field in the Online Environment. Proceedings of the International Conference on Business Excellence, 13(1), 1108-1117.

Reuters. (2017). What Can Publishers Do about "Fake" News? Erişim 11 Nisan 2021 https://agency.reuters.com/ 
Ritchie, H., Mathieu, E., Rodes-Guirao, L., Appel, C., Giattino, C., Ortiz-Ospina, E., Hasell, J., MacDonald, B., Beltekian, D., Dattani, S. \& Roser, M. (2021). Statistics and Research Coronavirus (COVID-19) Cases. Ourworldindata.org, Erişim $18 \mathrm{Ka}$ sım 2021 https://bit.ly/30D5V7q

Roberts, K. (2020). Locked Down Leisure in Britain. Leisure Studies, 35(5), 617-628.

Robertson, E., Reeve, K.S., Niedzwiedz, C.L., Moore, J., Blake, M., Green, M., Katikireddi, S.V. \& Benzeval, M.J. (2021).Predictors of COVID-19 vaccine hesitancy in the UK household longitudinal study. Brain, Behavior and Immunity, 94, 41-50.

Romer, D. ve Jamieson, K.H. (2020). Conspiracy Theories as Barriers to Controlling the Spread of COVID-19 in the U.S.. Social Science and Medicine, 263, 113356.

Roozenbeek, J., Schneider, C.R., Druhurst, S., Kerr, J., Freeman, A.L.J., Recchia, G., van der Bles, A.M. ve van der Linden, S. (2020). Susceptibility to Misinformation about COVID-19 around the World. Royal Society Open Science, 7(10), 201199.

Saied, S.M., Saied, E.M., Kabbash, I.A. ve Abdo, S.A.E.F. (2021). Vaccine Hesitancy: Beliefs and Barriers Associated with COVID 19 Vaccination among Egyptian Medical Students. Journal of Medical Virology. Erişim 11 Nisan 2021 https://cutt. ly/1c4YPmR

Sallam, M., Dababseh, D., Eid, H., Hasan, H., Taim, D., Al-Mahzoum, K., Al-Haidar, A., Yaseen, A., Ababneh, N.A., Assaf, A., Bakri, F.G., Matar, S. ve Mahafzah, A. (2021). Low COVID-19 Vaccine Acceptance is Correlated with Conspiracy Beliefs among University Students in Jordan. International Journal of Environmental Research and Public Health, 18(5), 2407-2420.

Scerri, M. ve Grech, V. (2020). COVID-19, Its Novel Vaccination and Fake NewsWhat a Brew. Early Human Development, 105256.

Schapals, A.K. (2018). Fake News: Australian and British Journalists' Role Perceptions in an Era of "Alternative Facts". Journalism Practice, 12(8), 976-985.

Schwartz, K. (2019). Millions Still Believe the 1969 Moon Landing Was a Hoax, VoaNews. Erişim 24 Mart 2021 https://cutt.ly/7c098Pk

Schwarz, N. \& Jalbert, M. (2020). When news feels true: Intuitions of truth and the acceptance and correction of misinformation. R. Greifeneder, M. Jaffé, E. J. Newman, \& N. Schwarz (Ed.), The psychology of fake news: Accepting, sharing, and correcting misinformation içinde,(73-89)., London: Routledge.

Schwarzinger, M., Watson, V., Arwidson, P., Alla, F., \& Luchini, S. (2021). COVID-19 vaccine hesitancy in a representative working-age population in France: a survey experiment based on vaccine characteristics. The Lancet Public Health, 6(4), e210-e221.

Solmaz, B., Tekin, G., Herzem, Z. ve Demir, M. (2013). Internet ve Sosyal Medya Kullanımı Üzerine Bir Uygulama. Selçuk İletişim Dergisi, 7(4), $23-32$.

Spring, M. (2020). COVID-19: Internette Yayılan Yalan Haberin Gerçek Kurbanları. 
BBC News. Erişim 7 Nisan 2021 https://cutt.ly/UcFiHFR

T.C. Sağlık Bakanlığı COVID-19 Bilgilendirme Sayfası Birincil vaka (saglik.gov.tr)

Tandoc, E.C., Lim, Z.W. ve Ling, R. (2018). Defining "Fake News": A Typology of Scholarly Definitions. Digital Journalism, 6(2), 137-153.

Türkiye İstatistik Kurumu (TUIK), (2019). https://bit.ly/2W4wBJR

Türkay, M., Ay, E.G. ve Aytekin, M.R. (2017). Antalya Illinde Seçilmiş Bir Grupta Aşı Karşııı Olma Durumu. Akdeniz Tıp Dergisi, 2, 107-112.

Usul, A.S. (2021). İlk CoronaVac aşısı Sağlık Bakanı Koca'ya yapıldı. Anadolu Ajansı, Erişim 18 Kasım 2021 https://bit.ly/3HxkcmT

Ülker, P. (2021). İnfodemi: Türkiye'de Yalan Haber Salgınında Artış. Deutsche Welle Türkiye, Erişim 5 Nisan 2021 https://cutt.ly/lcQ9Cid

Ünal, R. \& Taylan, A. (2017). Sağlık iletişiminde yalan haber-yanlış enformasyon sorunu ve doğrulama platformları. Atatürk Illetişim Dergisi Sağlık illetişimi Özel Sayısı, 14: 81-100.

Wang, N., Li, S. Y., Yang, X. L., Huang, H. M., Zhang, Y. J., Guo, H., Luo, C. M., Miller, M., Zhu, G., Chmura, A. A., Hagan, E., Zhou, J. H., Zhang, Y. Z., Wang, L. F., Daszak, P. ve Shi, Z. L. (2018). Serological Evidence of Bat SARS-Related Coronavirus Infection in Humans, China. Virologica Sinica, 33(1), 104-107.

Wardle, C. ve Derakshan, H. (2017). Information Disorder: Toward on Interdisciplinary Framework for Research and Policy Making. Council of Europe Report DGI(2017)09. Erişim 6 Nisan 2021 https://cutt.ly/yc4UtLm

Wardle, C. (2019). Understanding Information Disorder, First Draft. Erişim 11 Nisan 2021 https://firstdraftnews.org/

Yang, K. C., Torres-Lugo, C. ve Menczer, F. (2020) Prevalence of Low-Credibility Informaton on Twiter During the COVID-19 Outbreak. ArXiv E-prints. 2004-14484. Erişim 5 Nisan 2021 https://cutt.ly/ncWUOqW 